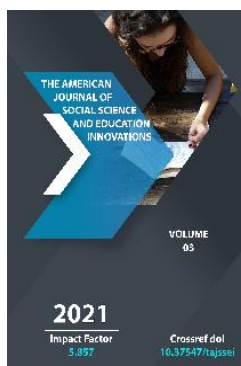

\title{
Comparative And Linguocultural Analysis Of The Concept "Gender" In Uzbek And English Languages
}

\author{
Komilova Nilufar Abdilkadimovna \\ Teacher, Department Of The English Language, Faculty Of Foreign Languages, Fergana State \\ University, Fergana, Republic Of Uzbekistan
}

Journal Website:

http://theamericanjour

nals.com/index.php/taj

ssei

Copyright: Original content from this work may be used under the terms of the creative commons attributes 4.0 licence.

\section{ABSTRACT}

The article under discussion reveals the issues of comparative and linguocultural analysis of the concept "gender" in Uzbek and English languages. The present study presents gender as a concept of linguistic culture and describes it as the basis that forms gender stereotypes on the material of phraseological units of English and Uzbek languages. The author of the article considers that gender is not a linguistic category, but its content can be revealed through the analysis of language structures, which explains the need for a linguistic study of the cultural representation of gender.

\section{KEYWORDS}

Comparative, linguocultural, gender, concept, analysis, cultural representation, masculinity, femininity, roles.

\section{INTRODUCTION}

The concept of "gender" is widely considered as a socio-cultural, discursive and psycholinguistic phenomenon. When studying the gender factor in language, a linguocultural approach is put forward, involving the study of masculinity and femininity as basic cultural concepts. The application of the gender approach is based on the methodological principle - understanding gender as a socially and culturally constructed phenomenon. Analysis of the expression of gender in language involves the representation of gender in language by means of linguistic resources and a whole system of factors (from ethnic and socio-cultural to individualpsychological). In speech behavior, women 
are characterized by deviations from the main topic and changes in roles; men tend not to deviate from the topic and interrupt the interlocutor more often [4, p.118].

In modern linguistics, gender features are considered in combination with status, social group, educational level, situational context and taking into account the changing situation in society. Interest in the ways of nominating persons of different gender and the gender category as such has deep roots: the relationship between the grammatical gender and the extralinguistic category "gender" is considered to be the most important one. The standard notion that women are more emotional than men leads to the fact that the same forms of speech behavior in men are interpreted as neutral and in women as emotional.

All linguistic studies of tendency are interdependent and complementary. The modern sociolinguistic model of language and speech functioning includes a structure of interdependent and interrelated components, connected, on the one hand, with physiological and neuropsychological features of the individual and, on the other hand, with the specificity of individual speech code formation under the influence of social (cultural, ethnic, etc.) and economic (belonging to a certain group, stratum, class, etc.) factors.

The analysis of men's speech represents the desire of men to restrain their emotionality (especially any manifestations of tenderness), using neutral vocabulary. The study of the means of expression of language units, conveying emotions in the speech of women, reveals emotionality, which is manifested at different levels. It is noted the desire of women to use, besides neutral, traditionally "feminine" vocabulary, rich in comparisons, metaphors, ellipses and rhetorical questions. When analyzing the intonation of male and female voices such phenomena as the speech competence of women, avant-gardism or conservatism, emotionality, social status and social speech are distinguished. The issue of speech (intonational) competence is determined by comparing female and male readings of the text in the group of the same social status. Educated women are as proficient in intonation norms for reading as men.

\section{MATERIALS AND METHODS}

In gender-linguistics "gender asymmetry" is of interest, because its study contributes to the deep study, and in some cases revision of the word-formation and nominative systems of language. In English against the background of certain achievements of feminism, reflected in the language (the appearance of such words as policewoman, man-eater, careerwoman), the male dominance is preserved, as only at the semantic level the category of gender appears. In English the concept "man" expresses the meaning "human", and the word "woman" has no this meaning. The English lexeme "man" denotes the concept "man" in a general sense and also takes over the designation of all the best qualities inherent in a person. As in many IndoEuropean languages, neutral words denoting persons of both sexes are masculine words. The formation of feminine words in English is made from the words of the male gender. The gender approach is based on the idea that it is not the biological or physical differences between men and women that matter, but the cultural and social significance that society attaches to these differences.

The present study presents gender as a concept of linguistic culture and describes it as the basis that forms gender stereotypes on 
the material of phraseological units of English and Uzbek languages. Gender is not a linguistic category, but its content can be revealed through the analysis of language structures, which explains the need for a linguistic study of the cultural representation of gender. L.Gordon considers gender to be a basic dimension of the social structure of society. Having compared different points of view of linguists, we can define gender as a concept or phenomenon of cognitive nature, manifested in the means of language and features of people's speech activity in connection with belonging to a certain gender [2, p.258].

\section{RESULTS}

In order to select exclusively gender-marked phraseological units from the general phraseological fund of the languages under study, we will propose the following criteria for the selection of gender-marked English and Uzbek phraseological units:

1. Grammatical criterion. In English, phraseological units with personal pronouns he (он - y), she (она - y), his (его - унинг), him (его, ему - унга), her (её - унинг, ей - унга) are gendermarked: His Majesty's servants актёры; he is so dumb you can sell him the Brooklyn Bridge - он набитый дурак - у мутлақо ахмоқдир. However, in many English proverbs with the personal pronoun he there is a phenomenon of gender neutralization and such proverbs can be used in relation to women: he laughs best who laughs last - хорошо смеётся тот, кто смеётся последним - охирги марта кулган киши яхши кулади. This is what is manifested in androcentrism in English grammar. In the Uzbek language, the identification of gender coloring of phraseological expressions with the help of grammatical criterion is difficult, because it has no pronouns, indicating a particular gender.

2. The morphological criterion primarily relies on the content of -er and -or suffixes in the structure of English phraseological units, indicating the male gender and the suffix -ess, indicating the female gender: stock actor - актёр, входящий в постоянную труппу определённого театра - маълум бир театрнинг доимий труппаси таркибига кирадиган актёр; meddling duchess суетящаяся дама, любящая командовать, но сама ничего не делающая - буйруқ беришни яхши кўрадиган, лекин ўзи хеч нарса қилмайдиган гавжум хоним.. However, not all English phraseological expressions containing the component with the suffix -er and -or denote the male gender, they can also denote a woman: high kicker - a frivolous girl who likes entertainment; cradle robber - who married someone much younger than herself.

3. Lexical criterion of selecting gendermarked phraseological expressions in English and Uzbek can be determined by the content of the following gender-indexed components:

a) Proper names, i.e. masculine and feminine names: Хўжа Ахрорнинг моли - these things belong to Hoja Ahrar (i.e. things that are not available to anyone); big John - a recruit.

b) Nouns, gender-marked lexemes indicating a particular gender: пайғамбар ёши - the age of the Prophet 
Muhammad (i.e., 63 years); оппоқ қиз - sweet girl (polite address to a girl); the old lady mother, old woman; liberty man - sailor on leave or furlough.

c) Gender-indexed kinship terms: оппоқ дада - grandfather; if mother could see us now

4. The semantic criterion of selecting gender-marked phraseological units is the most difficult, because English and Uzbek phraseology abounds with units that are not gender-marked by their component composition, but if we turn to the general meaning of these components, we can find that they denote either a man or a woman. Consider the Uzbek phraseology боши қоронғи pregnant (in the first period of pregnancy). If we dissect this phraseological unit into separate components, we obtain the lexemes бош - head and қоронғи dark. These individual lexemes are not gender-marked in any way, but together they formed a phraseological unit denoting a woman in the early stage of pregnancy. If we analyze the English phraseology lounge lizard a social bum, it also does not contain a gender component: lounge is a place for rest and entertainment, lizard is an animal (lizard). Together they denote a man who is not engaged in a certain business and likes to spend time in entertainment clubs and bars.
Thus, each of the listed criteria for selecting gender-marked phraseological units allows for certain changes or exceptions. Therefore, all the criteria should be applied together to clearly specify the gender nominated by the semantics of a particular phraseological unit.

Gender stereotypes identified on the material of English and Uzbek phraseology are divided into: 1) male stereotype; 2) the stereotype of a woman [2, p.137].

The gender stereotype functions at the level of the language system, as for the gender concept, it is represented much wider than the gender stereotype. The gender concept can be actualized at the lexical-phraseological level and at the level of entire texts. Not always the gender concept coincides with the gender stereotype, on the contrary, in modern English and Uzbek languages there is a certain discrepancy between gender stereotypes and gender concepts. Society develops, people's stereotypical opinions about existing or preexisting models of men and women change, and these changes do not always manage to be timely recorded and reflected in language, in particular in lexicographic sources [3, p.304].

The analysis of English phrases allowed us to build the following semantic classification:

1. External characteristics:

- $\quad$ Appearance: Teddy boy - олифта бола, muscles of steel - бақуват, а dolly bird (jarg.) - чиройли, олифта қиз, a glamour girl (coll.) - чиройли, гўзал қиз, a pin-up girl (am. ) - газета еки журналдан қирқиб олинган гўзал актрисанинг расми, а peroxide blonde - малла сочли қиз;

- Biological characteristics: the daughter of Eve (cf. Eve's daughter) - 
Еванинг қизи (аёл); the weaker vessel

- замонавий тилда аёл маъносида ишлатилинади;

- $\quad$ Age: a little man - ёш бола; an unlicked cub - қўпол ўспирин; an old cat, қари, жоғи тинмайдиган кампир; a bread and butter miss (jocular) - мактаб ёшидаги қизча;

- The reproductive function of a woman: in the family way (colloquially) - хомиладор;

- In English phraseological vocabulary a man is represented, on the one hand, as the strong sex: a man's man (coll.) хақиқий эркак; red blood - қўрқмас, ботир; play the man - ўзини эркак кишига хос тутиш; and, on the other hand, as a weak creature to characterize a woman-like, sentimental man: an old woman (derogatory) - ўзини номардларча тутиш; a Miss Nancy - мулойим, юмшоқ йигит.

2. Psychological characteristics:

- $\quad$ Moral and moral characteristics: ladies (lady's) man - хотинбоз; a drugstore (or drug-store) cowboy (am. jarg.) ишёқмас, ялқов; gay Lothario хотинбоз, a hot (warm) baby (am. jarg.) - енгилтак, бехаё қиз;

- $\quad$ Among the phrases addressed to a man, the characteristics of professionalism and craftsmanship stand out: Jack of all trades - қўли гул, мохир уста; Mr. Fixit - мохир, буюк уста.

- In English phraseology, a woman's intellectual abilities are evaluated negatively: dumb Dora (jarg.) / cousin Betty (coll.) - ақлсиз, нодон қиз;

- Women are attributed to talkativeness: old wives' tales - aëл кишининг миш-миш ва ғийбатлари; old wife - чақимчи;

- Female qualities include independence: mistress of the situation / to be one's own mistress ўз тақдирига эга булиш / тақдири ва хаётини ўзи хал қилиш; a woman of honor - халол ва тўғрисўз аёл.

3. Social characteristics:

- Marriage: Miss Right (colloquial) бўлажак умр йўлдоши (аёл); Mr. Right - бўлажак умр йўлдоши (эркак). The proverb 'a good husband makes a good wife' - яхши эрнинг аёли хам яхши - stresses the right of the man as the head and his responsibility for his partner [1, p.56];

- Relationships between people: one of the boys - вафодор одам; big boy қария, дўст; ladies first (colloquial) эркак аёлга хурмат билан йўл берганда;

- $\quad$ Family relations: like father, like son (adjective) - олмани олдига олма тушади;

- Unmarried life: a stag party (colloquial) - бўйдоқлар компанияси; single blessedness (joking) буйдоқлар хаёти;

- $\quad$ Kinship: half brother - ўгай акаукалар; sworn brothers - тутинган ака-укалар; (the) old lady - умр йўлдош.

1. Professional activities: a man of letters ёзувчи; business doctor - ишлаб чиқаришда маслахатчи; Tom Tailor чевар; the leading lady - бош ролдаги актриса. In this group are distinguished the phrases denoting professions related to law, army and navy, politics, etc. Socioprofessional activity is determinative for 
men and covers the most significant spheres of human activity [3, p.305].

\section{CONCLUSION}

Thus, a man's professional activity is extremely important for English-speaking society, since the amount of income and the prestige of a man's work determines his social status and that of his family as a whole. Social and economic reforms of the late twentieth century also influenced the role of women in society. Stereotypical ideas about the role of women, as represented in the phrases have undergone significant changes, which are naturally associated with the correctness of language.

\section{REFERENCES}

1. Gregory Titelman. (2000). Random House of America's Popular Proverbs and Sayings. Random House. P.56.

2. Gordon L. (1990). Gender and Higher Education in in the Progressive Era. New Haven, London: Yale University Press. P.258.

3. Jespersen J. (1998). The woman / the feminist critique of language / ed. by D. Cameron. L.,. 137 p.

4. Pokoyakova K.A. (2015). Osobennosti binarnoj oppozicii «muzhchinazhenschina» vo frazeologii $i$ paremiologii hakasskogo yazyka. Mir nauki, kultury, obrazovaniya.; 3 (52). p.p.304- 306.

5. Voloshina K.S. (2007). Gendernye razlichiya $v$ anglijskoj frazeologii: opyt sistemnogo analiza. Filologicheskie nauki. Vestnik Stavropol'skogo gosudarstvennogo universiteta.; 53. p.p.118 - 120. 